\title{
Aoristo)))))
}

International Journal of Phenomenology, Hermeneutics and Metaphysics

\section{Sobre a tríplice essêncía do amor}

\author{
On the threefold essence of love
}

\author{
Dax Moraes \\ Universidade Federal do Rio Grande do Norte - UFRN'
}

\section{RESUMO}

$O$ presente texto consiste em uma versão prévia de seção que compõe o livro $O$ acontecimento do amor, que aguarda impressão. (UFCSPA, 2020) Partindo da tese segundo a qual amor é liberdade (em sentido ontológico/transcendental), pretendemos apresentar sua tríplice essência como incondicionalidade, inegociabilidade e insubstituibilidade.

\section{PALAVRAS-CHAVE}

Amor; essência; liberdade; favor; temporalidade

\section{ABSTRACT}

This paper is a preview of a section written for the upcoming book $O$ acontecimento do amor [The happening of love]. (UFCSPA, 2020). Departing from the thesis according to which love is freedom (in an ontological/transcendental way), we intend to expose its threefold essence as unconditionallity, untradeableness and irreplaceableness.

\section{KEYWORDS}

Love; essence; freedom; favour; temporality

O amor sem causa e sem promessa, o amor que desperta e nada quer além de sua própria existência, cujo "sentimento" - dito melhor, consciência de sua presença

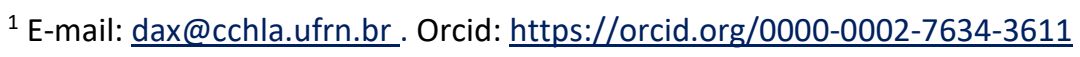




\section{Aoristo)))))}

\section{International Journal of Phenomenology, Hermeneutics and Metaphysics}

- por si só satisfaz, tendo como limite extremo um "amor platônico" sem sofrimento - bastante raro, caso exista -, se observa quando seus modos de expressão não são provas, mas fins em si mesmos. Afinal, toda prova tem como finalidade precisamente aquilo de que amor algum necessita: obter credibilidade. $\mathrm{O}$ amor, como aquilo que já se sabe, jamais necessita de qualquer artifício para que ganhe crédito, que o torne crível; se "não se crê" no amor, nada pode alterar essa convicção exceto o acontecimento do amor. O amor está para além ou aquém de toda crença, sendo, nesse sentido, por definição, incrível, tanto quanto extraordinário na medida em que não pertence a nenhuma "ordem natural das coisas". Aquilo que se sabe já é sempre digno de "confiança", ou "credibilidade", diferente daquilo em que apenas se crê e contrário a tudo que se quer dar a crer. Assim, o amor é o improvável por excelência. Em certo sentido é correto dizer que "provas de amor" só têm lugar onde não há amor, pois, se houvesse, nada haveria a ser provado.

Mas o prazer na ação se confunde com seu contrário, a alegria em fazer sentir prazer, e também com seu outro contrário, a alegria de dar prazer a si mesmo nestes dois últimos casos é que reconhecemos o fetichismo narcísico que norteia o desejo sexual. Fazer bem a si ou a outrem, por si só, não prova nada sobre o amor, e disso todos sabem sem ser necessário argumentar. Nenhum sentimento que acompanhe esse "fazer" pode lhe acrescentar algo à autenticidade desse suposto amor. Logo, ter prazer nos atos de amor como sentimento que os acompanha não basta ao testemunho de sua incondicionalidade. Essa incondicionalidade se verifica antes no silêncio das causas e na perplexidade diante desses atos - as expressões de amor tendem a ser sempre surpreendentes em alguma medida. $\mathrm{O}$ amor é verdadeiro quando incondicional não porque as ações ou sentimentos independam de quaisquer motivações, mas porque motivações não entram em cena como determinantes do amor como tal, apenas de suas expressões. $\mathrm{O}$ amor que surge de coisa alguma nada quer além.

É nesse sentido que o amor é aparentado a pensamento e vontade propriamente compreendidos, ou seja, fora do alcance do desejo como aquilo sobre o que não há poder ou possibilidade de constrangimento. Tampouco pode haver confusão entre $o$ amor, o pensamento e a vontade como tais e a reflexão a seu respeito, conforme observa Merleau-Ponty no primeiro capítulo da terceira parte de sua Fenomenologia da percepção: "o que é amar senão ter consciência de um objeto como amável?" (MERLEAU-PONTY, 2011, p. 504) Afinal, completa ele,

[...] amar e saber que ama são um único ato, o amor é consciência de amar, a vontade é consciência de querer. Um amor ou uma vontade que não tivessem consciência de si seriam um amor que não ama, uma vontade que não quer, assim como um pensamento inconsciente seria um pensamento que não pensa. (MERLEAU-PONTY, 2011, p. 504-505) 


\section{Aoristo)))))}

\section{International Journal of Phenomenology, Hermeneutics and Metaphysics}

Escreve ele mais adiante: "Meu amor, minha raiva, minha vontade não são certos enquanto pensamentos de amar, de odiar ou de querer, mas, ao contrário, toda certeza desses pensamentos provém da certeza dos atos de amor, de raiva ou de vontade, dos quais estou seguro porque eu os faço". (MERLEAU-PONTY, 2011, p. 511-512) Vale notar que está em jogo, no contexto de discussão do "cogito" cartesiano, o mesmo diagnóstico que já fora fundamentalmente expresso por Schopenhauer: a dúvida, a necessidade de provas ou demonstrações, de modo algum pertence àquilo que é imediatamente vivido, percebido, sentido, mas apenas à reflexão, aos objetos abstratos de nossa consciência mediata; o que é presente, enquanto presente, é sempre certo, mesmo quando se trate de um sonho, uma ilusão, uma alucinação - é ali tal como é para nós. Com certeza, também não temos poder algum sobre os sentimentos, mas estes são mero reflexo do que pensamos e do que queremos, do que somos, bem como de nosso amor ou desamor. Por isso mesmo se deve compreender que o amor não é uma ação, pois as ações quase nunca escapam à sua subordinação aos desejos e obrigações. Diferentemente das ações, o amor, como o pensamento e a vontade, não pode ser exigido ou reprimido - amor, pensamento e vontade estão do lado da verdade; a mentira só pode se dar nas ações e, por esse meio, enganar o amor, o pensamento e até a vontade. Amor incondicional (não-condicionante e nãocondicionado) é absurdo, uma fatalidade, um acontecimento que provém de nada e a nada se dirige. Alguns poderiam preferir dizer que é "espontâneo" - quanto a mim, não considero necessário pormenorizar que diferença isso faz. $\mathrm{O}$ amor incondicional é, portanto, "sem passado" e "sem futuro", sem explicação, sem sentido - por isso mesmo, puramente presente... a cada vez e a cada instante. Seu mistério é renovar-se como o mesmo, o que já sugere uma relação extraordinária com o tempo.

Porém, essa "característica", ou modo concreto de se dar a essência do amor, não responde completamente à questão sobre a essência do amor na medida em que, justamente por ser vaga, se não obscura e até controversa, a própria consciência comumente a perverte e confunde. Pela idealização do amado real, enquanto se mantêm as fantasias, pode-se pensar que esse amor é incondicional enquanto as condições estão sendo satisfeitas e não se concebe a possibilidade de deixarem de sêlo. O mais importante é que essa "característica" se opõe à concepção segundo a qual amor é escolha, fórmula que envolve sujeito e objeto determinados, bem como motivações. Toda escolha, segundo o entendimento comum, é uma ação intelectual, em alguma medida calculada e, como tal, não confere ao amor efetiva liberdade. É, antes, digamos, o amor que "escolhe", e quanto a isso Schopenhauer parece estar mais próximo da verdade quando afirma que a escolha amorosa não pertence ao amante, mas a um "instinto" ou "impulso" que ultrapassa e mesmo desconsidera seus interesses pessoais. De todo modo, a incondicionalidade consiste na pedra fundamental que coloca à parte a perspectiva estritamente teológica sobre o amor, embora ainda guarde excessiva afinidade com o domínio da moral quando a incondicionalidade é interpretada como desinteresse. Afinal, é muito difícil entender 


\section{Aoristo)))))}

International Journal of Phenomenology, Hermeneutics and Metaphysics

e até mesmo imaginar que "motivações não entrem em cena" no amor e, principalmente, que isso não signifique desinteresse ou indiferença, pois é justamente como desejo motivado pelo outro que o amor se mostra no corpo, como que dominando nossa fisiologia e nossos sentidos, mas este é um fenômeno derivado. $\mathrm{O}$ esclarecimento disso requererá uma abordagem sobre o amor em sua originariedade, questão reservada para outra oportunidade, à luz da qual deverão ser confrontados os casos derivados, ou casos de fato. Assim, a incondicionalidade própria ao amor autêntico deve se desdobrar segundo o tempo concretamente vivido, não entendida de modo abstrato como o fazem a Lógica ou a Ética.

Quando alguém ama sem ser correspondido, pode-se dizer que é um amor incondicional porque a ausência de retribuição nada significa para o amor feliz por amar, o que é muito diferente de querer dar mesmo que o outro não queira receber isto pode ser outra coisa bem diferente de amor, variando desde a indiferença da dádiva à mera obstinação em se fazer visível, notado. Neste último caso não há uma relação propriamente dita, enquanto naquele há uma relação, embora de mão-única, como, aliás, sempre é toda relação amorosa. A felicidade por amar se aproxima mais do que escreve Heidegger a Arendt na carta de 22/06/1925: "Nós só atuamos, conquanto estejamos em condições de dar; sendo indiferente se esta doação é sempre a mesma ou se ela será em geral acolhida". (HEIDEGGER apud LUDZ, 2001, p. 26) O amor verdadeiro não apenas prescinde de provas como também de contrapartida, de modo que a alegria em presentear apenas aumenta a partir de si mesma, como em uma espécie de "inchaço" - não é paga nem pagável pelo agradecimento -, e toda eventual contrapartida é somada ao próprio amor, que a incorpora em si - não constitui sua recompensa (toda recompensa é compensação, um crédito para saldar um débito). Esse "inchaço", que também se sente na "incorporação" do amor recebido - não em retorno, não em troca, mas dado em mão-única, independentemente do que quem dá recebera antes, daí chamar a isso "coincidência", a incidência concordante de duas ou mais casualidades -, corresponde a uma sensação ao mesmo tempo vaga e inconteste de que algo em nós infla, de que inflamos de fato e que isso pode ser visível para quem está por perto. $\mathrm{O}$ amor se fisiologiza. Normalmente essa sensação se confunde com um sentimento de excitação e diz-se que os olhos chegam a brilhar. A metafísica de Schopenhauer explica esse fenômeno mediante a identidade entre corpo e vontade, o primeiro como visibilidade da segunda, razão pela qual, conforme se lê nos manuscritos póstumos (I, §171[191]), "tanto abalam e modificam o corpo cada paixão, cada afeto, isto é, cada intenso querer e não querer". (SCHOPENHAUER, 2008, p. 106) Entretanto, o mais importante aqui não é o efeito, sentido e imediatamente manifesto, mas o que essa independência do amor com relação à contrapartida diz de sua essência temporal.

Isso significa, concretamente, que, nos "planos para agradar o amado", não se planeja o agrado do outro como se se estivesse planejando um investimento, determinado segundo expectativas de lucro futuro. Para investimentos, cabem as interferências da escolha previamente calculada em vista de um futuro 


\section{Aoristo)))))}

\section{International Journal of Phenomenology, Hermeneutics and Metaphysics}

determinado/determinante - aqui é flagrada uma motivação. Os "planos para agradar o amado", por sua vez, não vão além do próprio momento presente em que o agrado deve acontecer, no qual o amante se projeta e no qual vive a cada etapa da construção desse momento - pode-se dizer que o amado "vive para isso", como quem planeja uma festa com amor, não tendo em vista quem irá comparecer, falar bem ou falar mal, ou quaisquer outras formalidades sociais, ou o mero ocupar-se da "administração de um evento", mas a certeza de que será um "belo acontecimento". Ou seja, "viver para isso" significa não ter em "conta" a repercussão, mas realizar-se no processo que se esgota no momento "para o qual" se viveu, no qual já se vinha vivendo pelo amor e sua temporalidade própria. Trata-se de um continuum, não há a interposição de mais nada. Eis tudo o que pode significar, para um amor verdadeiro, querer o amor do outro: não a espera pelo que pode dele receber ou nele provocar, mas o estar presente ao seu acontecer, tê-lo junto ao próprio amor - nisso, o amor não passa a "valer a pena"; nisso, o amor se consagra como relação, pois o encontro aconteceu e fez-se espetacular. Aí, o objeto amado é superado, deixando de ser visto como pessoa de carne e osso, frágil mortal, para ser contemplado em sua beleza máxima e infinita como amante eterno. Escreve Heidegger a Arendt em 1/05/1925: "O direito à espera é para o amado o mais maravilhoso, pois justamente na espera a amada se faz "presente'". (HEIDEGGER apud LUDZ, 2001, p. 20) Pode-se ainda compreender por meio disso o significado autêntico do alheamento do amante pelo pensamento no amado, alheamento em que se faz ausente e "desligado" de suas atividades atuais, pois nessa outra temporalidade, não apenas o amado é trazido à presença, mas o amante mesmo se coloca em outro presente, o eterno presente do encontro. Ortega y Gasset parece dizer algo nesse sentido em seu ensaio "Amor em Stendhal", no final do §2:

Este é o sintoma supremo do verdadeiro amor: estar ao lado do amado, em um contato e proximidade mais profundos do que os espaciais. É um estar vitalmente com o outro. A palavra mais exata, embora demasiado técnica, seria: um estar ontologicamente com o amado, fiel ao seu destino, seja ele qual for. (ORTEGA Y GASSET, 1964b, p. 570)

Em "Feições do amor" também encontramos essa menção ao amor como "vivificação" no sentido de um dirigir-se a uma proximidade ontológica, não espacial, tratando-se, portanto, de uma consideração também relevante se se quer distinguir amor e desejo, cujo movimento, pelo contrário, exige proximidade física. $\mathrm{O}$ ato de amor é de outra natureza, bem como sua espera e seu propósito.

No ato amoroso, a pessoa sai de si: talvez seja a tentativa máxima que a natureza empreende para que cada um saia de si mesmo até outra coisa. Não ela em minha direção, mas eu em direção a ela gravito. [...] 


\section{Aoristo)))))}

\section{International Journal of Phenomenology, Hermeneutics and Metaphysics}

Não se trata, não obstante, que nos movamos fisicamente até o amado, que procuremos a aproximação e a convivência exterior. Todas essas ações exteriores nascem, certamente, do amor como efeitos seus, mas não nos interessam para sua definição [...]. (ORTEGA Y GASSET, 1964a, p. 554/556)

A despeito de, logo a seguir, Ortega y Gasset identificar o ato amoroso com um "processo na alma", em seu artigo "Para uma psicologia do homem interessante", II, a distinção é feita com devida clareza: "O fenômeno psicológico do desejo e o de "estar encantado'", que acrescendo, de minha parte, remeter à graça e ao favor do encontro amoroso, "têm sinal inverso", uma vez que o desejo faz com que se tenda a "absorver o objeto", ao passo que, no encantamento, "sou eu o absorvido", de maneira que "no apetite não haja entrega de meu ser, mas, pelo contrário, captura do objeto". (ORTEGA Y GASSET, 1966, p. 473) Ortega y Gasset acrescenta uma nota na qual aborda essa redução como um "erro de descrição psicológica" segundo o qual o fenômeno amoroso como tal é confundido ao com seus efeitos frequentes, enquanto que, na verdade, trata-se do "mais fecundo na vida psíquica": "Assim, de todo amor nascem desejos com relação ao amado, porém esses desejos não são o amor, mas, pelo contrário, o supõem porque nascem dele". Eis porque, permanecendo para aquém de suas manifestações e, desse modo, não sendo perceptível nele mesmo como objeto dos sentidos ou do intelecto, o amor tem uma realidade metafísica, é uma disposição originária que conforma o mundo a si, como que o antecipando. Como então poderia ser o amor algo de "condicionado"? De acordo com isso se pode ler em "A eleição no amor", II:

Contém nossa atitude primária e decisiva ante a realidade total, o sabor que o mundo e a vida têm para nós. O resto de nossos sentires, pensares, quereres, se move já sobre essa atitude primária e segue sobre ela, colorido por ela. Precisamente, o aspecto de nossos amores é um dos sintomas mais próximos dessa primeva sensação. (ORTEGA Y GASSET, 1964c, p. 603)

Nesse caso, entenda-se adequadamente o que significa esse caráter metafísico do amor: não o de algo "transcendente", mas transcendental. Ainda assim, não como uma espécie de "lei da experiência", antes como a própria forma da vivência.

Com isso, mais clareza e concretude se adquire sobre a essência do amor como liberdade. Em uma frase: Sempre o amor é inegociável. Dir-se-ia vulgarmente: "não tem preço". Não apenas dispensa mudanças; não as quer - confere dignidade a todas as qualidades que o tornam de fato resistente a qualquer tipo de "desilusão", coisa que a incondicionalidade do meu amor não garante sozinha. O caráter inegociável é o que dispensa ajustes e inviabiliza trocas, e dirige-se, portanto, especialmente ao outro, não a mim ou ao amor em si. Tal experiência não se realizaria adequadamente em um "amor a distância" no sentido em que se denomina "amor platônico", pois 


\section{Aoristo)))))}

\section{International Journal of Phenomenology, Hermeneutics and Metaphysics}

demanda envolvimento e proximidade, trata-se de amor declarado. Aqui, a graça do amor se revela no favor, que nada tem de mero cortejo ou comportamento estético. Não pode lhe bastar um "amor a distância", não porque a "proximidade" seja condição para contrapartidas, mas porque a "distância" não lhe basta, uma vez que a relação se realiza no encontro, e tal encontro, que é existencial, não algo em primeira instância físico, pode se dar mesmo a distância, quando esta é meramente espaçotemporal, exterior. Não se quer, portanto, que o outro seja outro, nem que se afaste, mas se lhe permite o afastamento. Antes se dizia apenas, de modo abstrato: "Sou o mesmo em meu amor ainda que o outro se torne outro". Se a primeira "característica" se refere ao caráter sem-fundamento do amor e seus atos, sua inexplicabilidade, esta segunda o distingue de outras relações de fato impedindo a mistura, por exemplo, entre amar e ser casado, conviver, compartilhar etc. $\mathrm{O}$ amor em si mesmo, que une pessoas, é independente e até mesmo paralelo de todo contrato ou costume que, como tais, sempre envolvem algum nível de negociação ou impessoalidade. Este modo concreto de dar-se a essência do amor, como o seguinte que o complementa, ao mesmo tempo humaniza o amor e combate sua sociologização, ou seja, sua redução à cultura e representações hipostasiadas em instituições.

Na segunda parte do Fausto (v. 9675-6), Goethe (2011, II, p. 428), baseado nas informações de Hederich em seu Léxico mitológico fundamental, que menciona uma série de roubos aos deuses empreendidos por Hermes - deus dos mercadores (e dos mentirosos, segundo alguns) - logo após seu nascimento, refere-se ao seu triunfo, já no dia em que nasceu, sobre Eros, dando-lhe uma rasteira em uma luta. O comércio "passa a perna" no amor tão-logo o encontra. A separação entre amor e negócio é necessária a fim de que o amor não deva nem possa ser reduzido aos contratos sobre ele estabelecidos. O caráter inegociável supõe o incondicional e contribui para sua perpetuidade no tempo, bem como a próxima "característica". O limite extremo é a invariação do amor submetido a relações fracassadas, nas quais o "negócio" faliu. Essa qualidade, como se vê, se opõe aos mitos da abnegação, da reciprocidade, da fusão e da autossuficiência, ou seja, aqueles que envolvem a redução de um às expectativas de outro, consistindo, portanto, em sua efetiva e simultânea liberalização. Ao lado disso, os atuais discursos sobre "adequação" se mostram vazios, se não dignos de reprovação. Se se sente a necessidade de adequar o que quer que seja, pode até haver amor, mas ele está sendo submetido a forças estranhas. Assim, a liberdade do amor, já manifesta como incondicionalidade abstratamente sabida, se torna vivida no encontro de singularidades irredutíveis.

Mais concreto é o fato, ele mesmo decorrente da inegociabilidade do amor, de que o amor pode não implicar uma convivência viável, e isso é mais amplo do que o contrato matrimonial. A essa altura, já é necessário destacar o terceiro elemento da tríplice essência do amor como liberdade. Aqui, peso especial adquire o passado no presente, mas o que está em jogo é, sobretudo e mais do que antes, o futuro. 


\section{Aoristo)))))}

\section{International Journal of Phenomenology, Hermeneutics and Metaphysics}

Acabamos de ver que amor e contrato, em si mesmos, por suas respectivas naturezas, excluem-se reciprocamente, sendo esta uma verdade essencial sobre os conflitos e desenganos que emergem das tentativas de harmonizar amor e casamento. Não se trata de dizer, como é usual, que o casamento "estraga" o amor, muito menos que isso se deve ao fato de as pessoas "se conhecerem melhor" no convívio diário e tudo o mais de semelhante. Tudo isso consiste em mero subterfúgio intelectual - portanto, abstrato - para se tentar explicar o que não se pode entender, mas que se deveria compreender. O caráter incondicional e inegociável do amor já atesta não ser esse o caso, muito embora o detalhamento desse tema nos levaria demasiado longe do propósito deste texto. Por ora, basta dizer que o fracasso dos contratos, como se sabe, nem sempre coincide com o fim do amor, o que significa que, com amor ou sem amor, independentemente do grau de convívio, o contrato simplesmente não pertence à essência do amor, seja a vigência desse contrato duradoura ou efêmera. $\mathrm{O}$ contrato é algo vindo de fora e estimulado por diversos fatores dentre os quais figuram o desejo de ter o amado sempre por perto e fantasias de fusão solidamente institucionalizadas pela Religião e pela Política. Aí temos, como exemplo, fatores psicológicos e sociais, mas o fator originário e ontológico, o único que mostra a impertinência do contrato às relações de amor, é também o único a favorecer uma compreensão adequada do que pode levar o amor a "esfriar" ou até destruir os meios de convivência.

Aliás, já é chegado o momento e é mesmo necessário eliminar desta discussão a palavra "convivência", pois "viver em conjunto", ou "ter uma vida em comum", não é de modo algum possível no rigor das palavras, exceto do ponto de vista da fantasia de fusão que está por trás disso e da concepção de casamento como "tornar-se uma só carne e um só espírito". Não se pode "caminhar nos sapatos de outro", como dizem os ingleses, estar em seu lugar e viver a sua vida. Tais expressões são absolutamente vazias, abstratas, e parecem supor um paraíso perdido, exceto quando se trata de metáforas para indicar a constituição dos filhos e da entidade "família" como célula ou átomo social, não uma nova condição existencialmente concreta do casal. O casal é sempre um complexo, e o frequente distanciamento mediante o nascimento dos filhos nada tem a ver, ao contrário do que apostava Schopenhauer, com uma espécie de "dever cumprido" para com a espécie, mas com o fato de esse complexo dar lugar a novos complexos relacionais que se multiplicam geometricamente. Por isso é que a presença de uma criança - não a criança ela mesma, deve-se ressaltar - pode igualmente unir, reunir ou separar um casal, até mesmo unir e separar ao mesmo tempo segundo o ponto de vista ou alternadamente, transformando a vida do casal em uma espécie de montanha russa.

Dito isso, a terceira "característica" se revela quando o amor que se tem diz respeito a um encontro que se dera no passado, porém "não mais agora", e pressupõe o caráter incondicional e inegociável do amor, mas no limite de sua concretude, pois a presença do amado, quando "sentida", o é de modo especial. Aquele encontro existencial, mesmo a distância, perdura, demora-se, ressoa, ainda 


\section{Aoristo)))))}

\section{International Journal of Phenomenology, Hermeneutics and Metaphysics}

que paralelamente a outros encontros. A verdade que aí se revela sobre o amor é a de que: Cada amado, e por extensão, cada amor é insubstituível. Ao contrário de se concluir que todo amor verdadeiro deva ser também "primeiro e último", pode-se compreender, de modo deflacionado, que todo amor verdadeiro é eterno no sentido de que "dura para sempre". Esta afirmação de modo algum se compromete com qualquer tipo de exclusividade, palavra cujo significado também exige revisão se se quer lhe conferir lugar autêntico no que concerne à essência do amor. A afirmação, pelo contrário, permite a multiplicidade, embora proíba a hierarquização - confere dignidade ao amado e exclui a impossível simultaneidade estrita de amores diversos. $\mathrm{O}$ amor dignifica o passado na proporção em que não recusa sua dignidade no futuro, e assim permanece livre de amarras e aberto ao "passar do tempo" e suas mudanças.

Há quem se torture ao deparar com um "novo amor" como se isso fosse ofensa a um "amor mais antigo", o que acomete, sobretudo, no contexto de uma viuvez precoce ou após o fim de um relacionamento que gerou filhos. Em si, esse sentimento de autocensura é positivo, pois é uma espécie de alerta interno para uma verdade à primeira vista contraditória, mas, na realidade, o que é contradito é um mito. A má compreensão dessa verdade pode levar a uma série de consequências desastrosas sem sequer se precisar tomar em consideração os costumeiros ciúmes do "novo amado". Por exemplo, quem ama pela "segunda vez" pode se ver obrigado tanto a menosprezar o "primeiro amor" como inferior sob diversos aspectos a fim de sepultá-lo e permitir que entre o "amor real", como também pode adotar a atitude contrária de evadir-se do "novo amor" segundo a produção de fantasias várias a respeito o "amor que se viveu" ou "ainda se vive". No primeiro caso, se produz artificialmente uma hierarquia; no segundo, a hierarquia mesma é bloqueada, mas por razões equivocadas, pois o bloqueio, e até mesmo o caráter insubstituível do amor que se venera, ou apenas se respeita, não tem em vista a verdadeira dignidade de todo amado, mas apenas de um, como nos consagrados exemplos literários das viúvas que se recusam a "voltar a amar" e mesmo a amar pela primeira vez. Em cada caso de desvio, é comum que a crença na profundidade e constância dos próprios sentimentos se veja abalada, e com razão, pois em cada caso se faz intervir juízos de valor (que incluem sempre estimativas e, portanto, uma ordem hierárquica) absolutamente estranhos ao amor considerado do ponto de vista da sua essência. Aliás, escrevo "primeiro", "segundo", "novo" entre aspas porque, considerando a persistência do amor em detrimento do tempo exterior no qual os amados se sucedem, evocar uma ordem é um contrassenso. Refiro-me, portanto, às representações temporais que nos levam a enfileirar os atores de nossa história pessoal.

Como cada um é singular e irredutível, não há como comparar um amor a outro, não há propriamente "amar mais" ou "amar menos". Apenas se pode amar diferentemente, por mais semelhantes ou hierarquizáveis que possam ser os prazeres $e$ 


\section{Aoristo)))))}

International Journal of Phenomenology, Hermeneutics and Metaphysics

os valores anexados à relação pela reflexão, pelo desejo e pelo sentimento - esses prazeres e valores podem ser maiores ou menores, mas não na medida do amor, e, sim, da espécie de singularidade que o caracteriza ou acompanha. Eis porque cabe melhor aqui a oposição ao mito da exclusividade, pelo qual não há apenas uma redução do outro, mas sua anulação, pois a exigência de exclusividade nada oferece, antes retira, ao passo que a oferta é uma oferenda, graça e favor, um sacrifício do amor, o contrário de todo desejo de posse. Trata-se, então, de uma síntese (no sentido de unidade, não de superação) das duas características anteriores - "O amor é o mesmo, ainda que eu ou o outro sejamos outros em nossos sempre diferentes amores". Se nada pode ditar a mudança no amor, que não está em meu poder, e se isso se estende a qualquer transformação no outro, em mim ou em minha relação com ele, o que agora é livre é o próprio amor de ambos, posto que é livre do homem, livre da mulher - não porque é dom divino, mas por ser ele mesmo "divino". Esta é a contribuição maior para uma ontologia do amor, recuperando-lhe a transcendência, imutabilidade e a eternidade, ao mesmo tempo eliminando em suas consequências a confusão estabelecida pela própria filosofia acerca de tudo isso. Esse amor não rompe apenas com a causalidade e com a cotidianidade atarefada, mas com a própria temporalidade exterior, física, na qual transcorrem as assim chamadas "histórias de vida". Feliz pelo que foi na condição de "sempre terá sido", a possibilidade do compartilhamento, em vez de "divisão" ou mera "justaposição" por comunhão de bens, se torna a virtude amorosa por excelência. Trata-se de compreender que "outros amores" não são ameaça para "este amor".

Em sua primeira fala no quarto ato da segunda parte do Fausto (v. 10060-6), diz o protagonista em alusão à sua perdida Gretchen:

Tesouros juvenis jorram-me do imo peito, Que em vibração etérea o amor de Aurora evoca, O êxtase do primeiro olhar, o qual de súbito A alma penetra e que tesouro algum iguala. Cresce em beleza espiritual o ameno vulto; Não se esvanece, e ao alto se ala adentro do éter, E de meu fundo ser leva o melhor consigo

(GOETHE, 2011, II, p. 464-465).

Eis uma imagem da perene presença do "ter amado" no presente, com a qual se poderia encerrar o presente texto, muito embora traga, ao fim, a insistência na figura do desconsolo expressa no ter perdido o melhor de si mediante a ausência física do ser amado.

Entretanto, uma última e crucial observação deve ser feita se cada amor é insubstituível, se não há meios de medi-lo segundo o que se dá e se recebe e, finalmente, se os encontros acontecem por feliz e raro acaso: há sempre a possibilidade de amores simultâneos, cujo impasse gerado será sempre e para sempre insolúvel, apesar de já ter sido dito acima que uma simultaneidade estrita seja 


\section{Aoristo)))))}

\section{International Journal of Phenomenology, Hermeneutics and Metaphysics}

impossível. O que emerge agora é que sempre será uma arbitrariedade escolher um amor em detrimento de outro e sempre será uma injustiça colocar um amor acima do outro sob qualquer pretexto - também assim o elemento essencial do insubstituível realiza a síntese geral dos anteriores, o incondicional e o inegociável. Dito de outro modo, os referidos desvios da escolha e da hierarquização são soluções para a vida cotidiana, nada mais do que isso, e aí se deve incluir aqueles que, na tentativa de se evadir do impasse, procuram fazer uso simultâneo dos amores - simultâneo, aqui, tomado em sentido usual. Quando digo se tratar de um impasse insolúvel, o digo no rigor das palavras: não é que não se "deva" viver mais de um amor por vez, mas que não se pode viver duas vidas ao mesmo tempo - simultaneidade no sentido estrito -, apenas alterná-las; o que se "pode" é ter em si mais de um amor, de maneira que a incompatibilidade entre a eternidade do amor e a temporalidade da vida se revela em toda sua gravidade justamente aqui! A impossibilidade de se tomar uma decisão revela, ademais, que não há decisão a ser tomada, coisa alguma a se fazer, senão com o risco certo de se cometer uma injustiça ou algo pior - contra si, contra o outro e contra o próprio amor. Sempre alguma decisão "deverá" ser tomada, é verdade, mas sempre será injusta, não importa o bem que traga para as vidas envolvidas, mesmo que para todas elas. $\mathrm{O}$ amor não aceita nenhum pragmatismo. Badiou, embora sem estar se referindo necessária e explicitamente a amores simultâneos, toca também nesse ponto em seu pequeno e tão completo livrinho que tangencia a perfeição: "todo mundo sabe que decidir o fim de um amor, sobretudo unilateralmente, é sempre um desastre, quaisquer que se sejam as excelentes razões que se apresente" (BADIOU; TRUONG, 2011, p. 53) - todo o belíssimo trecho do qual são extraídas essas palavras é digno de nossa máxima atenção.

Há expressões bastante extremadas de decisão para dar fim ao amor, que podem variar na proporção em que o impasse se mostre subjetivamente insolúvel "objetivamente" sempre haverá "soluções". O Werther de Goethe poderia ter tido um belo futuro se fosse "equilibrado e paciente" e, por amor, aguardasse um novo amor "tão merecido", mas isso não apenas não se deu (ao menos no romance) como jamais poderia ter livrado seu coração de Charlotte - talvez, o esquecimento? Não em seu caso, decerto. Aguardar um novo amor quando se está certo de amar para sempre um amor atual é como querer e premeditar a injustiça contra o que mais se ama ou, se não, assumir para si que o amor atual não haverá de perdurar, o que seria uma contradição no seio do amor e, portanto, ausência de amor - daí o suicídio de Werther como sacrifício do amor, não por fraqueza de espírito, tampouco mera vingança contra o amor ele mesmo. Não se deve entender a "contradição", de todo modo, como a oposição de duas determinações dadas, um absurdo lógico, e, sim, como o absurdo de se ter uma dicotomia no seio daquilo que é em si mesmo singular - é impossível contradição no amor justamente porque nele apenas vigem possibilidades, o que o coloca acima de toda lei. Mas há aí mais do que mera contradição, a qual só se aplica propriamente a juízos ou conceitos, a construções 


\section{Aoristo)))))}

\section{International Journal of Phenomenology, Hermeneutics and Metaphysics}

intelectuais sobre o real. O suicídio de amor é, em verdade, ambíguo, pois é cometido conscientemente em virtude da ausência do amado, mas também, igualmente, pela inextinguibilidade de sua presença. Não se trata, enfim, de uma questão objetiva de custo-benefício. Qualquer "decisão" será sempre injusta porque entraram em cena razão e sentimento, em conjunto ou em separado - o amor terá sido submetido e não poderá fazer ninguém feliz, pois sempre um pedaço lhe terá sido roubado por quem "decidiu". Nesse caso, como em qualquer outro, parece caber a sentença: "Não sobreviver ao amor - por conseguinte, ao amado - pode ser nossa única chance!".

Abrindo um parêntese sobre esse ponto tão sensível e frequentemente banalizado, mesmo quando se the confere "a maior importância", vale a pena chamar a atenção para o fato de que, no estrito rigor da expressão, o suicídio de amor, quiçá o suicídio em geral, é sempre equívoco. Essa palavra, não obstante tenha adquirido um sentido quase moral que se quer evitar aqui, indica que dois significados (ou motivos), por vezes inconciliáveis e reciprocamente excludentes, têm o mesmo peso e o mesmo valor (a mesma voz). A mera ambiguidade não contempla esse campo semântico de modo apropriado e suficiente. Pior do que isso, o "ambíguo" tende a ser interpretado como algo de caráter "insinuante", "indefinido", muito mais afeito ao cômico do que à tragicidade inerente ao suicídio. Mas agora surge uma nova dificuldade oriunda do uso corrente da língua: o suicídio é trágico não em virtude das terríveis circunstâncias materiais da morte, de seu caráter violento, mas esse caráter é antes a expressão de uma tragicidade mais originária, que consiste no ponto de encontro de duas fatalidades ineludíveis das quais não se pode escapar senão pela autossupressão. Gostaria de ilustrar tudo isso lançando mão de dois exemplos bem conhecidos, e assim, talvez, evitar que essas considerações sejam tidas como extravagantes. Não parece casual que o mais recorrente símbolo trágico seja Édipo. Ele, contudo, não se suicida. Sua automutilação apenas expressa sua cegueira com relação à descoberta da equivocidade ineludível de esposo e filho, pai e irmão. Sábio e resignado, comporta-se como herói ao invés de cometer o ato vão de Jocasta, que nada tem de trágico. Inteiramente diverso é o duplo suicídio de amor de Romeu e Julieta, que nada tem em si mesmo de determinado pelo conflito entre suas respectivas famílias. Shakespeare os poupou de semelhante desfecho mediante o artifício de um pacto de morte, que nada teria de trágico. Apenas o segredo de Julieta produz o encadeamento que leva tanto Romeu quanto ela mesma a perecerem a fim de escaparem do equívoco de ausência do outro no mundo e presença do outro em si, mas o verdadeiro equívoco era de morte e vida. Contudo, a tragicidade é mais pura na morte de Romeu, pois é livre de culpa. É interessante observar também que, por exemplo, Szondi (2004, p. 89-94) reconhece a equivocidade (sem usar a palavra) como centro da tragédia edipiana, mas a vê de maneira um tanto tradicional, situando-a ao longo da trama sob uma forma tríplice e gradual.

De volta ao assunto, amores simultâneos - cuja ameaça já se anuncia nos chamados "triângulos amorosos" - não são coisa que se queira, são menos desejáveis do que qualquer rejeição, e, quando se dão, sempre de súbito, como todo amor em 


\section{Aoristo)))))}

International Journal of Phenomenology, Hermeneutics and Metaphysics

particular, são como uma maldição pelo impasse insolúvel que instalam, fazendo coincidir no tempo exterior do mundo o que não pode ser conciliado por sua própria natureza. Por isso, parece ser menos crucial a multiplicidade de amores que, do ponto de vista do tempo exterior, sempre apenas se sucedem, de um modo ou de outro. Por outro lado, os amores simultâneos revelam o amor em sua totalidade como um absurdo, mas desde que haja honestidade bastante para o amante compreendê-lo. Nessa revelação, a singularidade de cada amor se mostra em contraste à vida cotidiana e à temporalidade superficial que a abriga e encerra e, desse modo, fecha-se o círculo, nos sendo dado a compreender, em um relance, que nossa vivência se desdobra existencialmente (ou antes se exprime) em duas dimensões irredutíveis e inconciliáveis em si mesmas: a de nossas relações essenciais com os outros e a de nossas relações atarefadas com as coisas do mundo.

Um caso especial de "triângulo amoroso" é aquele que une genitores e seu filho. Propositadamente não o desenvolvo no presente momento, em parte porque a saída do dilema - nesse caso tão corriqueiro - já se encontra previamente estabelecida pela cultura, ainda que de modo tácito. Uma abordagem adequada exige que o sentido da geração por amor seja previamente pensado de modo próprio, o que, por si só, exige um trabalho à parte e mais moderado para o qual temos aqui uma simples indicação mediante a explicitação da tríplice essência do amor. Em breves palavras, apenas para não deixar em branco algo cuja seriedade exige de nós toda a atenção, justamente em virtude da "saída" imprópria ordinariamente tomada, pode-se adiantar que se trata de um fenômeno no qual os genitores tendem a se evadir no exclusivismo das respectivas relações com o filho, de um lado, e, de outro, evadiremse um do outro enquanto se enclausuram em suas respectivas ocupações. Ou seja, é o modo mais acessível de se lançar ao absurdo do amor inadvertidamente, mas como se de maneira premeditada, tornando-se uma experiência tão comum que, infelizmente, não se tem olhos para ver o que ensina. Por isso, a força do tema é ofuscada desde a raiz.

\section{REFERÊNCIAS}

BADIOU, A; TRUONG, N. Éloge de l'amour. Paris: Flammarion, 2011.

GOETHE, J. W. Fausto: uma tragédia. Trad. Jenny Klabin Segall. Apres. Coment. e notas Marcus

Vinicius Mazzari. ed. bolso. São Paulo: 34, 2011. 2v.

LUDZ, U. (Org.). Hannah Arendt-Martin Heidegger: correspondência 1925/1975. Trad. Marco Antonio Casa Nova. Rio de Janeiro: Relume Dumará, 2001.

MERLEAU-PONTY, M. Fenomenologia da percepção. Trad. Carlos Alberto Ribeiro de Moura. São

Paulo: M. Fontes, 2011.

ORTEGA Y GASSET, J. Facciones del amor. In: ORTEGA Y GASSET, J. Obras completas, tomo V (1933-

1941). 6. ed. Madrid: Revista de Occidente, 1964a. p. 551-559. 


\section{Aoristo)))))}

International Journal of Phenomenology, Hermeneutics and Metaphysics

Amor en Stendhal. In: ORTEGA Y GASSET, J. Obras completas, tomo V (1933-1941). 6. ed. Madrid: Revista de Occidente, 1964b. p. 561-596.

. La elección en amor. In: ORTEGA Y GASSET, J. Obras completas, tomo V (1933-1941). 6. ed. Madrid: Revista de Occidente, 1964c. p. 597-626.

. Para una psicología del hombre interesante (Conocimiento del hombre). In: ORTEGA Y GASSET, J. Obras completas, tomo IV (1929-1933). 6. ed. Madrid: Revista de Occidente, 1966. p. 467-480. SCHOPENHAUER, A. Schopenhauer im Kontext III: Kompletausgabe. Berlin: Karsten Worm InfoSoftWare, 2008. 1 CD-ROM.

SZONDI, Peter. Ensaio sobre o trágico. Rio de Janeiro: J. Zahar, 2004.

Submetido: 28 de maio de 2020

Aceito: 26 de junho de 2020 